\title{
Wiedza chorych na temat zagrożeń wynikających z przyjmowania leków przeciwzakrzepowych i antyagregacyjnych ze wskazań kardiologicznych
}

\section{Patients' awareness of the threat of taking antithrombotic and antiplatelet agents due to cardiological recommendations}

\author{
Maria Korzonek ${ }^{1}$, Małgorzata Zembik² \\ 1 Samodzielna Pracownia Opieki Długoterminowej Pomorskiego Uniwersytetu Medycznego w Szczecinie \\ ul. Gen. Dezyderego Chłapowskiego 11, 70-103 Szczecin \\ Kierownik: dr n. med. Maria Korzonek \\ 2 Oddział Internistyczny Szpitala Powiatowego w Gryfinie \\ ul. Parkowa 5, 74-100 Gryfino \\ Kierownik: lek. med. Kamila Dzięgielewska
}

\section{STRESZCZENIE}

Wstęp: W kardiologii leki przeciwzakrzepowe i antyagregacyjne są powszechnie stosowane. Poza działaniem terapeutycznym, leki te wykazują wiele objawów niepożądanych.

Celem pracy była ocena wiedzy chorych na temat działania oraz możliwych powikłań przyjmowanych leków antyagregacyjnych i przeciwzakrzepowych ze wskazań kardiologicznych.

Materiał i metody: Badaną grupę stanowiło 180 pacjentów (średnia wieku 65 lat). Metodą badawczą był sondaż diagnostyczny wykorzystujący kwestionariusz autorski.

Wyniki: Spośród leków antypłytkowych i przeciwzakrzepowych przyjmowanych przez chorych najczęściej, u 140 osób, stosowano kwas acetylosalicylowy, klopidogrel - u 64 osób, a pochodne acenokumarolu przyjmowało 25 osób. Na pytanie, czy chory uzyskał informacje na temat ubocznych działań przyjmowanych leków
$51 \%$ odpowiedziało że tak, $22 \%$, że nie, a $27 \%$ nie pamiętało. Swoją wiedzę na temat działania leków jako dobrą oceniło 23\%, jako średnią 57\%, brak wiedzy deklarowało 20\%. Zagrożenia związane z nagłym odstawieniem leków znało tylko 25\% badanych. Aż $81 \%$ chorych nie wiedziało, jak należy postąpić w przypadku pominięcia dawki leku.

Wnioski: Stan wiedzy pacjentów na temat leczenia przeciwzakrzepowego, powikłań, skutków ubocznych, interakcji jest niedostateczny, a sposób i zakres edukacji pacjentów jest niewystarczający. Wobec powszechności stosowania leczenia przeciwzakrzepowego powinny powstać na wzór zachodnich ośrodków poradnie antykoagulacyjne.

Słowa kluczowe: leki antypłytkowe, leki przeciwzakrzepowe, wskazania kardiologiczne.

\section{SUMMARY}

Introduction: Nowadays, antithrombotic and antiplatelet agents are widely used in cardiology. Both agents, apart from their therapeutic benefits, have many adverse effects.

The main aim of the study was to assess the awareness and knowledge of side effects and possible complications in patients taking antithrombotic and antiplatelet agents due to cardiological recommendations.

Material and methods: A sample of 180 patients (mean age 65 years) was studied. A diagnostic survey based on a questionnaire prepared by the researchers was used for measurements. Results: The results indicated that among antithrombotic and antiplatelet agents taken by patients the most often used were: acetylsalicylic acid (140 patients) and clopidogrel (64 patients), while acenocoumarol derivatives were taken by 25 patients. When asked whether the patient obtained information about the side effects of drugs $51 \%$ of patients acknowledged obtaining information, $22 \%$ of patients denied that they were given such information, and $27 \%$ of patients admitted that they had forgotten whether they were informed about side effects. $23 \%$ of patients described their knowledge of the effects of drugs as wide, $57 \%$ of patients as basic, and $20 \%$ of patients admitted a lack of knowledge in that area. $25 \%$ of patients knew the threats of sudden discontinuation of treatment. $81 \%$ of patients could not describe management in the case of missing a dose of the drug. Conclusions: The results suggest that in patients on antithrombotic treatment the state of knowledge about complications, side effects and interactions of drugs is insufficient. The methods and scope of education are inadequate. Considering the widespread use of antithrombotic treatment, anticoagulation clinics should be established.

Key words: antiplatelet agents, antitrombotic drugs, cardiological recommendations.

\section{WSTĘP}

Według Światowej Organizacji Zdrowia (World Health Organization - WHO) około 5 mln osób rocznie umiera z powodu chorób sercowo-naczyniowych, w tym prawie 2 mln w krajach Unii Europejskiej. W Polsce rocznie umiera 90 tys. kobiet i 80 tys. mężczyzn. W krajach wysoko rozwiniętych schorzenia te zajmują pierwsze miejsce wśród przyczyn zejść śmiertelnych [1]. 
Rozwój kardiologii sprawił, że obecnie więcej osób przeżywa po przebytych ostrych zespołach wieńcowych, groźnych zaburzeniach rytmu, po operacjach na sercu w krążeniu pozaustrojowym, a to niewątpliwie za sprawą powszechnej profilaktyki i terapii przeciwzakrzepowej [2].

W kardiologii istnieje wiele wskazań do podjęcia leczenia antyagregacyjnego i przeciwzakrzepowego. Należą do nich: napadowe lub utrwalone migotanie przedsionków, niewydolność serca, ostry zespół wieńcowy, stabilna i niestabilna choroba wieńcowa, a w kardiochirurgii stan po operacji by-pass, czyli pomostowania aortalno-wieńcowego (CABG), po operacji tętniaków aorty wstępującej, łuku i aorty piersiowej, po wycięciu pozawałowych tętniaków serca, po przeszczepieniu serca, po wszczepieniu biologicznych lub sztucznych zastawek serca, po zabiegach wykonywanych w krążeniu pozaustrojowym [3, 4]. Ponadto leki te mają zastosowanie w prewencji i leczeniu żylnej choroby zakrzepowo-zatorowej (ŻChZZ), u chorych po przebytym udarze niedokrwiennym mózgu, po wielu zabiegach chirurgicznych [5], profilaktycznie w ortopedii i traumatologii narządu ruchu.

Pacjenci poddani tej terapii powinni być informowani o możliwych zagrożeniach wynikających ze skutków ubocznych działania leków. Niezbędna jest wiedza na temat interakcji z innymi lekami, wpływu produktów spożywczych, suplementów diety, ziół, używek oraz wysiłku fizycznego na farmakokinetykę oraz farmakodynamikę leków przeciwzakrzepowych i antyagregacyjnych. Konieczne jest, aby chorzy informowali o kuracji przeciwzakrzepowej lekarzy innych specjalności, przede wszystkim dentystów, chirurgów, ginekologów czy urologów [6]. Szczególnego znaczenia nabiera świadoma współpraca pacjenta z lekarzem oraz akceptacja przez chorego prowadzonego leczenia i systemu kontroli, pamiętając, że dawki leku zmieniają się w zależności od aktualnego stanu zdrowia, diety, stanu emocjonalnego (stres) i wielu innych czynników [7].

Celem pracy była ocena świadomości, a także stanu wiedzy chorych przyjmujących leki antyagregacyjne oraz przeciwzakrzepowe ze wskazań kardiologicznych na temat ich działania i możliwych powikłań.

\section{MATERIA I I METODY}

Badania przeprowadzono w grupie 180 osób (57 kobiet i 123 mężczyzn), pacjentów Szpitala Specjalistycznego w Pile Oddziału Kardiologicznego z Pracownią Hemodynamiki, Pracowni Endoskopowej SPSK nr 2 w Szczecinie, pacjentów laboratorium przy Przychodni Lekarza Rodzinnego „Vitamed” w Gryfinie, Prywatnych Gabinetów „Sonomed” w Szczecinie oraz pacjentów Oddziału Internistycznego Szpitala Powiatowego w Gryfinie.

Przeprowadzono sondaż diagnostyczny z wykorzystaniem kwestionariusza autorskiego złożonego z 30 pytań dotyczących wiedzy chorych na temat prowadzonej terapii i możliwości wystąpienia niebezpiecznych powikłań. W interpretacji wyników pomiaru uwzględniono czynniki fizjologiczne (wiek), społeczne (stan cywilny, wykształcenie) oraz patologiczne (choroby współistniejące). Badanie było anonimowe, udział w badaniu dobrowolny.

\section{WYNIKI}

Spośród badanych najliczniejsza grupę (63 osoby) stanowili pacjenci w przedziale wiekowym 61-70 lat i 51-60 lat (49 osób). W przedziałach wiekowych 30-40 lat była 1 osoba, 41-50 lat 26 osób, 71-80 lat 40 osób, powyżej 80 lat 1 osoba. Dominowali pacjenci z wykształceniem zawodowym - 79 osób i średnim55 osób, natomiast 29 respondentów miało wykształcenie podstawowe, a 17 - wyższe. W badanej grupie 6 osób było stanu wolnego, w formalnych związkach małżeńskich 139 osób, owdowiałych 21, rozwiedzionych 12, żyjących w konkubinacie 2.

Najliczniejszą grupę wśród badanych stanowiły osoby chorujące na serce od niespełna roku - 54 osoby (30\%), do 3 lat trwania choroby - 31 osób (17\%), 4-6 lat - 29 osób (16\%), do 8 lat - 21 osób (12\%), a ponad 10 lat - 45 osób (25\%).

Większość badanych - 107 osób (59\%) deklarowało, że nie pali papierosów. Palących krócej niż 10 lat było 10 osób (6\%), do 20 lat $12(7 \%)$, palących ponad 20 lat $51(28 \%)$.

Leki przeciwzakrzepowe i antyagregacyjne badanym najczęściej przepisywali lekarze o specjalności kardiologicznej 127 (70\%), lekarze POZ 21 (23\%) i kardiochirurdzy 12 (7\%).

Najczęściej, u 140 chorych (78\%) stosowany był kwas acetylosalicylowy, następnie klopidogrel - u 64 (35\%), a pochodne acenokumarolu przyjmowało 25 (14\%). Należy uwzględnić, że w badanej grupie 70 osób (39\%) przyjmowało 2 lub więcej leki z tej grupy.

Najczęstszą przyczyną stosowania terapii lekami przeciwkrzepliwymi była choroba wieńcowa i zawał serca (83 osoby $46 \%$ ), następnie zaburzenia rytmu pod postacią migotania przedsionków ( 22 osoby - 12\%), wada serca (18 osób - 10\%) i stan po wszczepieniu sztucznej zastawki (11 osób - 6\%).

W badanej grupie jedynie $51 \%$ badanych twierdziło, że uzyskali informacje na temat działań ubocznych przyjmowanych leków. Aż 22\% chorych nie otrzymało żadnej informacji, a 27\% nie pamiętało, czy otrzymało takie informacje (ryc. 1).

Większość badanych - 108 osób (60\%) przyznała, że informacje o lekach pochodzą od lekarza, 78 (43\%) - z ulotki dołączonej do leku, 28 (15\%) - od pielęgniarki, 4 (2\%) - z Internetu, 3 osoby $(1,6 \%)$ - z piśmiennictwa. Można zauważyć brak

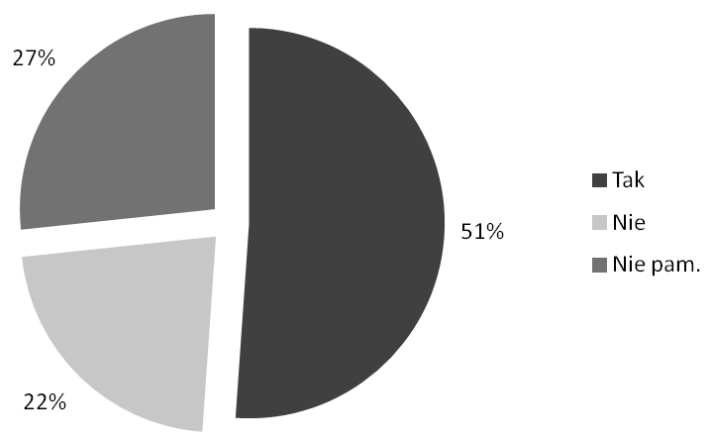

RYCINA 1. Rozkład ilościowy pacjentów, którzy uzyskali informacje na temat leczenia 


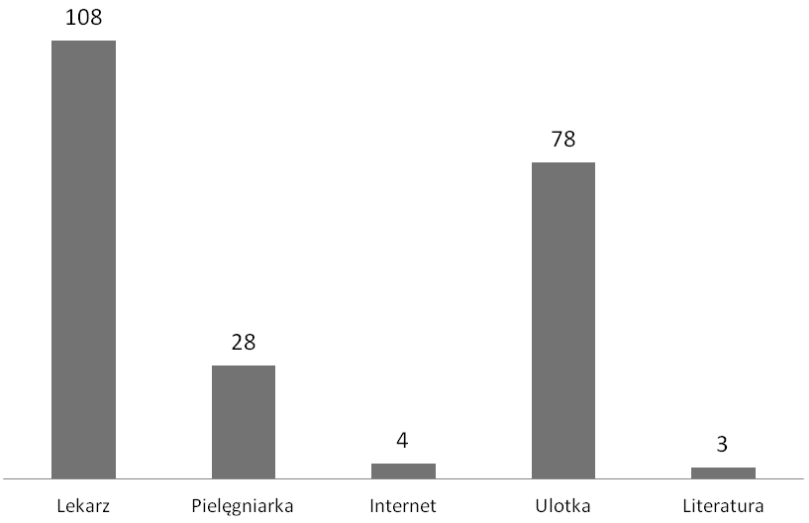

RYCINA 2. Pochodzenie informacji na temat leczenia

konsekwencji w odpowiedziach, gdyż część osób uprzednio deklarujących, że nie otrzymało informacji o leku, następnie podaje np. lekarza lub pielęgniarkę jako źródło swojej wiedzy. Część osób posiadało wiedzę z dwóch lub więcej źródeł (ryc. 2).

Swoją wiedzę na temat działania leków jako dobrą oceniły 42 osoby (23\%), jako średnią 103 (57\%), brak wiedzy deklarowało $35(20 \%)$ - rycina 3.

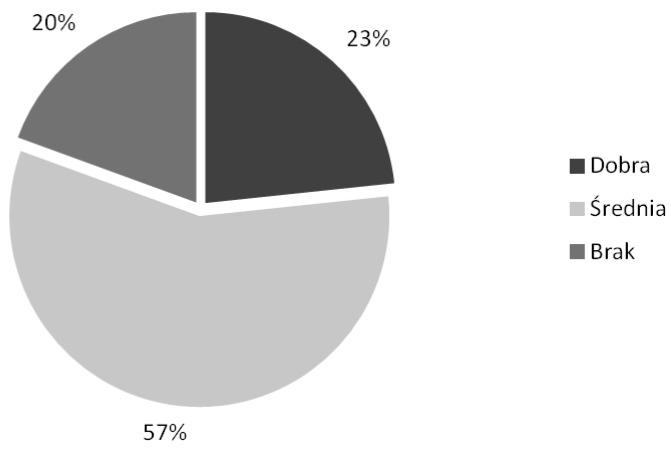

RYCINA 3. Samoocena wiedzy na temat leczenia przeciwzakrzepowego

Pacjenci zostali zapytani, czy żywienie i niektóre produkty spożywcze, w tym owoce i warzywa wpływają na działanie przyjmowanych leków: 87 osób (48\%) odpowiedziało tak, natomiast 93 (52\%) uważało, że pokarm nie ma wpływu na działanie leków. Wpływ równocześnie przyjmowanych innych leków na działanie leków przeciwzakrzepowych uznało 101 osób (56\%), negowało 79 (44\%). Negatywne skutki działania przyjmowanych leków potrafiło wymienić 27 osób (15\%), pozostałe 153 (85\%) ich nie znało. U 154 (84\%) osób nie wystąpiły incydenty krwawienia, jednak u 26 (14\%) pojawiły się takie objawy, jak: krwawienia z nosa u 13 osób, krew w stolcu u 7, krwawienia z jamy ustnej u 2, z gardła u 1, a wymioty krwawe u 1. Spośród badanych 6 osób (3\%) było hospitalizowanych z powodu wystąpienia krwawienia związanego z przyjmowanymi lekami. Na pytanie o znajomość objawów krwawienia z żołądka i dwunastnicy 157 osób (87\%) odpowiedziało, że nie zna objawów, a 23 osoby (13\%), że zna. Jednak na pytanie, o czym świadczy obecność czarnego stolca tylko 65 osób (36\%) potrafiło odpowiedzieć prawidłowo. Badanie wskaźnika INR regularnie

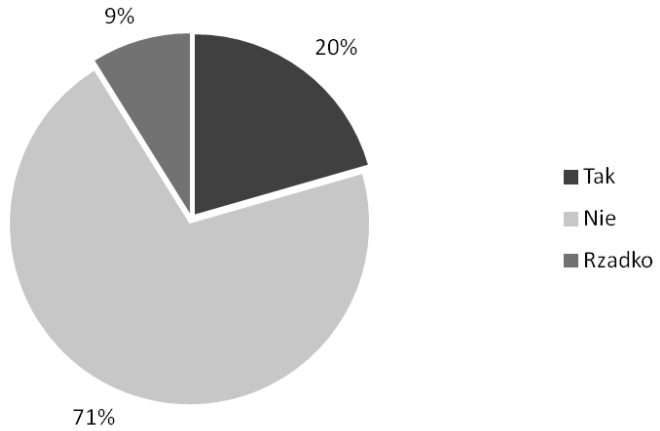

RYCINA 4. Regularne kontrolowanie INR

kontrolowało 37 osób (20\%), rzadko 16 (9\%), nie kontrolowało wcale $127(71 \%)$ - rycina 4 .

Znajomość prawidłowej wartości INR zadeklarowało 37 osób (21\%), a pozostałe 143 (79\%) jej nie zna. Większość chorych 151 osób - 84\%) wiedziało o konieczności informowania innych lekarzy o przyjmowanych lekach, ale 29 (16\%) osób nie posiadało tej wiedzy. Prawidłowe postępowanie w przypadku pominięcia dawki leku znały 34 osoby (19\%), natomiast 146 (81\%) nie wiedziała, jak należy postąpić. Podobnie, jak w sytuacji konieczności nagłego odstawienia leków przeciwkrzepliwych aż 135 osób (75\%) nie posiadało wiedzy na temat następstw, a prawidłową odpowiedź znała $1 / 4$ ankietowanych, tj. 45 osób. Znajomość leków przeciwgorączkowych, jakie można przyjmować w trakcie leczenia przeciwzakrzepowego wykazało 21 osób (12\%), zdecydowana większość - 159 (88\%) tego nie wiedziała. Podobnie w przypadku leków przeciwbólowych. Jedynie 35 pacjentów (19\%) znało preparaty, jakie mogą bezpiecznie stosować, natomiast aż 145 (81\%) ich nie znało. Jedynie 52 osoby (29\%) przyznały, że zostały poinformowane, iż reklamowane w mediach powszechnie dostępne bez recepty leki mogą być dla nich niebezpieczne, a wręcz szkodliwe, natomiast przeważająca większość - 128 osób (71\%) tej wiedzy nie posiadało.

\section{DYSKUSJA}

Leki przeciwzakrzepowe i antyagregacyjne uważane są za „złoty standard” w terapii wielu chorób o podłożu sercowo-naczyniowym, znajdując szerokie zastosowanie zarówno w kardiologii, jak i w kardiochirurgii. Niemniej jednak starzejąca się populacja pacjentów jest bardziej narażona na występowanie objawów ubocznych i groźnych powikłań wynikających z terapii tymi lekami. W badaniach własnych średnia wieku wynosiła 65 lat. Ryzyko wystąpienia powikłań w tej grupie chorych jest szczególnie wysokie z powodu wieku, współistnienia wielu chorób oraz stosowania różnorodnych leków. Postęp w medycynie sprawił, że życie ludzkie ulega stopniowemu wydłużaniu, zatem wzrasta liczba chorych wymagających leczenia antyagregacyjnego i przeciwzakrzepowego. Efekt terapeutyczny tych środków zależy od wielu czynników farmakokinetycznych modulujących wchłanianie bądź szybkość metabolizmu leku, a także od czynników farmakodynamicznych. Dlatego też niezbędna jest wiedza, jakie leki, 
produkty spożywcze, suplementy diety, zioła i używki mają wpływ na farmakokinetykę oraz farmakodynamikę leków przeciwzakrzepowych i antyagregacyjnych. Ponadto pacjenci przyjmujący leki przeciwzakrzepowe powinni być informowani o możliwych zagrożeniach wynikających ze skutków ubocznych działania tych środków. Konieczne jest również, aby chorzy informowali o terapii przeciwzakrzepowej lekarzy innych specjalności, np. dentystów, chirurgów, ginekologów, urologów [6]. Należy podkreślić, że u chorych, u których zostały tymczasowo odstawione doustne antykoagulanty wzrasta ryzyko wystąpienia powikłań zakrzepowo-zatorowych. W tej sytuacji szczególnego znaczenia nabiera dobra współpraca pacjenta z lekarzem, akceptacja leczenia i poczucie odpowiedzialności obu stron za skuteczną terapię. Według wyników przeprowadzonych badań głównym źródłem informacji dla pacjentów są lekarze oraz ulotki dołączone do leku. Niewątpliwie w edukację pacjentów powinny włączyć się wykształcone pielęgniarki, których udział jest, jak wykazano w przeprowadzonych badaniach, niewielki. Brak wyczerpujących informacji sprawia, że nie wszyscy chorzy informowali lekarzy innych specjalności o prowadzonej terapii. Większość, 151 osób (84\%), deklarowała, że podaje, jakie leki przyjmuje, ale $29(16 \%)$ nie posiadało tej wiedzy. W edukowaniu pacjentów istotne znaczenie ma nie tylko wiek, ale także wykształcenie. Sawicka-Powierza i wsp. badali rolę edukacyjną pielęgniarki środowiskowej w opiece nad pacjentami leczonymi lekami przeciwzakrzepowymi w poradni lekarza rodzinnego. Wykazali, że osoby starsze oraz osoby z wykształceniem podstawowym wymagają dłuższej edukacji oraz większego zaangażowania personelu medycznego nadzorującego postępy pacjenta [8]. W badaniach własnych dominowali pacjenci z wykształceniem zawodowym i średnim, a jedynie 9,5\% chorych posiadało wyższe wykształcenie. Stwierdzono, że wykształcenie nie miało wpływu na poziom wiedzy respondentów. Należy podkreślić, że forma ustna przekazu informacji jest zdecydowanie niewystarczająca. Pacjenci, często w podeszłym wieku, z zaburzeniami pamięci, powinni posiadać odpowiednio zredagowane materiały edukacyjne, przystępnie i jasno informujące o działaniu leku, jego skutkach ubocznych i powikłaniach. Przekonują o tym wyniki badań własnych, gdzie jedynie 92 osoby ( $51 \%$ badanych) przyznają, że uzyskały informacje na temat działań ubocznych przyjmowanych leków.

Co zatem sprawiło, że prawie połowa, tj. 49\% respondentów, twierdziła, że nie uzyskało informacji na temat możliwych działań ubocznych związanych z prowadzonym leczeniem, bądź tego nie pamiętało. Dlaczego tak istotne wiadomości nie trafiły i nie zostały zapamiętane przez chorych? Niewątpliwie najgroźniejszym powikłaniem leczenia przeciwzakrzepowego są krwawienia, zwłaszcza z przewodu pokarmowego. Najbardziej narażone na nie są osoby w podeszłym wieku, obciążone dodatkowo innymi schorzeniami, jak choroba wrzodowa, nowotwory złośliwe, czy niewydolność nerek, a także przyjmujące inne leki upośledzające hemostazę, jak niesterydowe leki przeciwzapalne (NLPZ) [9].

Niestety, wyniki badań własnych wskazują na niedostateczną wiedzę chorych w tym zakresie. Ponad połowa badanych nie wiedziało, że NLPZ, popularna aspiryna i jej odpowiedniki, czy antybiotykoterapia zwiększają ryzyko wystąpienia krwawienia z przewodu pokarmowego. Stąd niebezpieczne stają się leki nabywane w tzw. sprzedaży odręcznej, przyjmowane bez konsultacji z lekarzem, a często reklamowane w mediach. Duża liczba chorych (przyjmuje się, że w Polsce ok. 7 mln osób) cierpi na schorzenia reumatyczne i zmiany zwyrodnieniowe stawów oraz kręgosłupa, z czego niemal połowa dodatkowo do zaordynowanej kuracji stosuje leki dostępne w sprzedaży odręcznej, głównie z grupy NLPZ. Szacuje się, że powikłania będące skutkiem długotrwałego przyjmowania NLPZ są powodem ponad 2800 zgonów w Polsce w ciągu roku [10]. Połączenie terapii przeciwzakrzepowej z niekontrolowanym stosowaniem przez pacjenta NLPZ wyraźnie zwiększa ryzyko incydentów krwawienia [10, 11]. Jak wykazali Michalski i Kasprzak, powołując się na wyniki amerykańskich badań publikowanych w takich stowarzyszeniach, jak Amerykańskie Towarzystwa Kardiologiczne i Gastroenterologiczne, Amerykańskie Kolegium Gastroenterologii, Amerykańskie Kolegium Fundacji Kardiologii, Amerykańskie Stowarzyszenie Serca, w populacji chorych przyjmujących NLPZ u jednej na 20 osób i u jednej na 7 osób w wieku podeszłym występują powikłania ze strony przewodu pokarmowego. Ryzyko zwiększa się 2-4 razy przy równoczesnym stosowaniu NLPZ i ASA [10, 12]. Każdy chory poddany terapii przeciwzakrzepowej powinien kontrolować międzynarodowy współczynnik znormalizowany INR. Utrzymanie go w przedziale terapeutycznym, zalecanym w konkretnym schorzeniu, warunkuje powodzenie leczenia oraz w znacznym stopniu ogranicza ilość możliwych powikłań $[13,14]$. Według wyników badań, ryzyko krwawień u chorych leczonych lekami przeciwkrzepliwymi jest niskie, gdy wartości INR są stabilne i mieszczą się w przedziale między 2,0 a 3,5 [15]. W przeprowadzonych badaniach wykazano, że jedynie $21 \%$ ankietowanych znało zalecaną dla nich wartość INR i tyleż regularnie kontroluje jego poziom. Niewątpliwie wiedza na temat znaczenia systematycznej kontroli czynnika INR z pewnością wpływa na bezpieczeństwo terapii. Potwierdzają to badania Sawickiej-Powierzy i wsp., które wykazały, że pacjenci posiadający podstawową wiedzę dotyczącą leków przeciwkrzepliwych częściej badały INR [8]. Obecnie w niektórych krajach edukacja chorych i oznaczanie INR odbywa się w wyspecjalizowanych przychodniach przeciwkrzepliwych, tzw. klinikach antykoagulacyjnych (anticoagulant clinics), bądź w domu pacjenta za pomocą koagulometru [16]. Specjaliści tam zatrudnieni są doskonale przygotowani do przekazu informacji chorym na temat terapeutycznych przedziałów INR, koniecznej częstości oznaczania tego współczynnika, dawkowania i sposobu modyfikacji dawki leku zależnie od sytuacji, możliwych powikłań, interakcji z pożywieniem i innymi lekami, postępowania w przypadku drobnych zabiegów inwazyjnych związanymi z naruszeniem ciągłości tkanki $[17,18,19]$. System taki istnieje na całym obszarze Holandii. Jak wykazały przeprowadzone analizy, funkcjonowanie klinik antykoagulacyjnych istotnie wpłynęło na poprawę jakości leczenia, częstości oznaczeń wskaźnika INR, znacznie zredukowało liczbę powikłań zatorowych i krwotocznych, a także przyczyniło się do wydatnych 
oszczędności finansowych w systemie opieki medycznej, gdyż spadła liczba hospitalizacji i porad udzielanych na oddziałach pomocy doraźnej [18]. Z kolei w Niemczech wprowadzono program samokontroli, gdzie chorzy za pomocą aparatów do oznaczenia INR (np. Coagu Check) samodzielnie wykonują badanie z kropli krwi pobranej z palca. Przeprowadzone analizy ujawniły, iż odsetek właściwych wyników wyniósł 78-92, co pociągnęło za sobą 50\% redukcję łącznego ryzyka powikłań zakrzepowo-zatorowych oraz powikłań krwotocznych [19]. Niestety, w Polsce nie funkcjonują specjalistyczne poradnie antykoagulacyjne. Opiekę nad pacjentami sprawują lekarze różnych specjalności. Bywa, że pacjenci nie są informowani przez personel medyczny o czynnikach mających wpływ na działanie przyjmowanych leków, ani o konieczności kontroli i utrzymaniu wskaźnika INR w zalecanych przedziałach [17, 20]. Na rynku pojawiły się profesjonalne urządzenia, tzw. analizatory INR, służące do samokontroli w warunkach domowych, ale ich koszt jest dla wielu pacjentów zbyt wysoki. Toteż w praktyce wielu chorych nie jest właściwie leczonych, co z jednej strony jest związane z utrudnionym dostępem do specjalistów, a z drugiej z niedostateczną współpracą, lub jej brakiem ze strony chorego lub jego rodziny [21]. Wpływ na krzepliwość krwi i tym samym na wskaźnik INR mają sytuacje, gdy dochodzi do pominięcia dawki leku lub konieczności jego nagłego odstawienia. W badaniach własnych wykazano, że prawidłowe postępowanie w przypadku pominięcia dawki leku znało jedynie 19\% badanych, natomiast aż $81 \%$ nie wiedziała, jak należy postąpić. Podobnie jak w sytuacji konieczności nagłego odstawienia leków przeciwkrzepliwych. Aż 75\% badanych nie wiedziało, jakie mogą być tego następstwa, a prawidłową odpowiedź znała zaledwie $1 / 4$ ankietowanych. Potwierdzają to odpowiedzi udzielane na kolejne pytania. Jedynie $48 \%$ badanych zgodziło się, że spożywany pokarm ma wpływ na metabolizm leków. Wynika z tego, że pacjenci nie zdając sobie sprawy z wpływu stosowanej diety, ziół czy suplementów na działanie przyjmowanych leków nie informują lekarza o sposobie odżywiania, czy przyjmowaniu „niegroźnych” witamin czy ziół. Nie podejrzewają, że przebyta infekcja, biegunka, podwyższona temperatura ciała a nawet zwiększona aktywność fizyczna mogą wpływać na efekty leczenia.

Należy podkreślić, że obecnie niezbędnym jest upowszechnienie praktyki wydawania dokumentów w postaci legitymacji, gdzie poza danymi pacjenta, jego schorzeniami, zamieszczone są nazwy i dawki przyjmowanych leków, zalecany przedział terapeutyczny INR, wyniki pomiarów, najistotniejsze informacje dotyczące powikłań, niepożądanych objawów, zagrożeń, interakcji leków przeciwzakrzepowych z innymi lekami, pokarmami, sposobów postępowania w przypadku wystąpienia niepokojących objawów. Zamieszczony jest również wykaz tych zabiegów diagnostycznych, gdzie nie jest wymagane przerwanie leczenia, a także informacja o konieczności informowania innych specjalistów o przyjmowanych lekach. Ta forma zabezpieczenia pacjenta zdała już egzamin w diabetologii, zatem niewątpliwie należy ją powielać. Wobec narastającej liczby chorób układu sercowo-naczyniowego oraz starzejącej się populacji pacjentów przyjmujących leki przeciwzakrzepowe i antyagregacyjne głównie ze wskazań kardiologicznych, jedynie wszechstronna edukacja chorych pozwoli na świadome wyeliminowanie zagrożeń, jakie niesie ze sobą tego typu terapia.

\section{WNIOSKI}

1. Stan wiedzy pacjentów na temat leczenia przeciwzakrzepowego, powikłań, skutków ubocznych, interakcji jest niedostateczny.

2. Sposób i zakres edukacji pacjentów jest niewystarczający.

3. Wobec powszechności stosowania leczenia przeciwzakrzepowego, powinny powstać na wzór zachodnich ośrodków poradnie antykoagulacyjne.

4. Należy rozpowszechnić i dostosować do fizycznych oraz intelektualnych możliwości chorych materiały dotyczące leczenia, a także związanych z tym działań niepożądanych.

5. Aby ułatwić monitorowanie poziomu INR, należy zapewnić pacjentom, szczególnie tym, którzy mają utrudniony dostęp do specjalistów, możliwość badania go w domu za pomocą nieodpłatnego sprzętu.

\section{PIŚMIENNICTWO}

1. Lasota B., Mizia-Stec K., Gąsior Z.: Postępy w terapii chorób serca na przełomie ostatnich lat. Świat Med Farm. 2009, 9, 58-66.

2. Rewiuk K.: Niewydolność serca i migotanie przedsionków - gdy nieszczęścia chodzą parami. Chor Serca Naczyń. 2009, 6 (2), 49-57.

3. Kleinrok A., Adamczyk T.: Powikłania krwotoczne po farmakomechanicznym leczeniu ostrych zespołów wieńcowych. Część I - definicje, występowanie, znaczenie i czynniki ryzyka. Post Kardiol Interw. 2009, 5 (2), 81-91.

4. Trzeciak P., Poloński L., Zembala M.: Powikłania krwotoczne i zakrzepowo zatorowe u chorych ze sztuczną zastawką serca - nadal niedoceniany problem, wciąż bez bezpiecznych rozwiązań. Kardiol Pol. 2006, 64, 1038-1042.

5. Burzyńska J., Gruchała M., Rynkiewicz A.: Jak stosować leki przeciwpłytkowe u pacjentów $\mathrm{z}$ chorobą niedokrwienną serca lub ekwiwalentem wieńcowym? Forum Med Rodz. 2009, 3 (2), 99-107.

6. Sawicka-Powierza J., Oltarzewska M., Chlabicz S.: Postępowanie z pacjentami leczonymi doustnymi lekami przeciwkrzepliwymi podczas leczenia stomatologicznego. Czas Stom. 2007, 60 (10), 691-698.

7. Stępińska J.: Współpraca z pacjentem leczonym przeciwzakrzepowo Med Dypl. 2008, 3 (8), 17-20.

8. Sawicka-Powierza J., Ołtarzewska A.M., Chlabicz S., Rogowska-Szadkowska D., Marcinowicz L.: Edukacyjna rola pielęgniarki środowiskowej w opiece nad pacjentami leczonymi acenokumarolem w poradni lekarza rodzinnego. Pol Merkuriusz Lek. 2009, 26 (15), 636-639.

9. Windyga J.: Powikłania leczenia przeciwzakrzepowego. Med Dypl. 2007, 16 (4), 37-42.

10. Michalski B., KasprzakJ.D.: Leki antyagregacyjne w kardiologii. Jak uniknąć powikłań? Lek Rodz. 2009, 15 (3), 256-266.

11. Imela J., Opolski G., Rydzewska G., Baczewska-Mazurkiewicz D., Małecki R., Filipiak K.J.: Konsensus Grupy Roboczej powołanej przez konsultantów krajowych w dziedzinach chorób wewnętrznych, gastroenterologii i kardiologii w sprawie zasad prewencji powikłań żołądkowo-jelitowych z przewodu pokarmowego w trakcie leczenia przeciwpłytkowego. Kardiol Pol. 2009, 67 (5), 536-538.

12. .Wójcik P., Mulak A.: Leczenie przeciwpłytkowe i antyagregacyjne a ryzyko krwawienia z przewodu pokarmowego. Gastroenterol Pol. 2009, 16 (5), 383-388.

13. Rewiuk K., Grodzicki T.: Migotanie przedsionków jako problem ludzi starszych. Kardiol Pol. 2009, 67 (9), 149-156. 
14. Dobrowolski P., Kosiński P., Filipiak K.J.: Leki przeciwkrzepliwe w chorobach serca i naczyń - stan obecny i perspektywy. Chor Serca Naczyń 2007, 4 (3), 130-136

15. Aframian D.J., Lalla R.V., Petersom D.E.: Management of dental patients taking common hemostasis-altering medications. Oral Surg Med Oral Pathol Oral Radiol Endod. 2007, 103 (45), 1-11.

16. Wołkanin-BartnikJ., Zieliński T., Pogorzelska H., Browarek A., Leszek P., Korewicki J.: Powikłania zakrzepowo-zatorowe i krwotoczne u pacjentów po wszczepieniu sztucznej zastawki serca leczonych doustnymi lekami przeciwzakrzepowymi. Czynniki ryzyka zależne od jakości leczenia przeciwzakrzepowego. Pol Arch Med Wew. 2005, 114, 673-679.

17. Sawicka-Powierza J., Rogowska-Szadkowska D., Ołtarzewska A.M., Chlabicz S.: Czynniki wpływające na działanie doustnych antykoagulantów. Interakcje z lekami i pożywieniem. Pol Merkuriusz Lek. 2008, 24 (143), 458-462.
18. Trzeciak P., Foremny J., Szyguła-Jurkiewicz B., Zembala M.: Poradnia wad serca - system opieki ambulatoryjnej nad chorym po zabiegu wszczepienia sztucznej protezy zastawkowej. Prewencja infekcyjnego zapalenia wsierdzia oraz powikłań krwotocznych i zakrzepowo-zatorowych. Fam Med Primary Care Rev. 2006, 8 (4), 1328-1334.

19. Sawicka-Powierza J., Ołtarzewska A.M., Rogowska-Szadkowska D., Chlabicz S.: Stosowanie doustnych antykoagulantów w ramach opieki ambulatoryjnej. Pol Merkuriusz Lek. 2008, 24 (143), 463.

20. Ołtarzewska A., Sawicka-Powierza J.: Program poprawy jakości opieki nad pacjentami leczonymi doustnymi antykoagulantami (DAK) w akademickiej praktyce medycyny rodzinnej w Białymstoku. Doniesienia zjazdowe. Probl Med Rodz. 2008, 10 (2), 73-75.

21. Szymczyk T., Płaczkiewicz D., Kleinrok A.: Migotanie przedsionków w pytaniach i odpowiedziach. Kardiol Dyplom. 2008, 7 (7), 65-70. 